\title{
Online Identification of Weaknesses of Subjective Tests in Javanese Course Assessment: A Case Study of Second Grade Students at SMAN 2 Malang
}

\author{
Natanael F. Rahmanda ${ }^{1, *}$ Miftachul Amri ${ }^{1}$ Syamsul Sodiq ${ }^{2}$ \\ ${ }^{1,2}$ Language and Literature Education, Universitas Negeri, Surabaya, Indonesia \\ *Coresponding author. Email: natanael.20025@mhs.unesa.ac.id
}

\begin{abstract}
The current pandemic has had a significant impact on the learning evaluation process in schools. One type of subjective test assessment is also affected by the imposition of a form of distance learning. This study aims to identify the weaknesses of the subjective test given online to second-grade students SMAN 2 Malang. This research method is qualitative by using a case study approach. Researchers made observations in collecting data that were then observed and interpreted to identify the weaknesses of the online subjective test. The results show that there are three forms of weakness in the implementation of evaluations using online subjective tests: economic inequality, lack of validity, and the level of student laziness. Students cannot be objects to blame because the integration of the teacher to make changes and adjustments is also important. Adjustment is focused on selecting other types of tests that must be adjusted, such as the form being changed from written to oral.
\end{abstract}

Keywords: Subjective test, Weakness, Online.

\section{INTRODUCTION}

The current state of the pandemic forces all lives that humans also live to move more dynamically. Various fields of life must also adapt to rules that affect all community activities, including in the world of education. One of the immediate impacts felt by all elements of education is the cessation of teaching and learning activities in schools, because the current pandemic situation forces every form of a crowd to be avoided. So we need the right solution to continue teaching and learning activities because it is also impossible to stop the learning process.

The influence on the assessment process with the distance learning process must really be considered to the maximum so that the learning objectives can be achieved optimally. Information intended for this evaluation must be obtained validly to determine student development, especially in this online learning process. The assessment used can be packaged in quizzes, online tests, individual assignments, or other forms of online assessment by utilizing internet access [1]. One form of collecting information on student development is through assessment, using the form of a test given to students. In the end, the teacher will get feedback from students to measure the level of development they want to measure. The evaluation carried out by the teacher must be systemic, which includes the initial behavior of students and the professional attitude of the teacher [2]. The form of the chosen test also varies, depending on what realm the teacher wants to measure, and one form of test that is often the choice is the subjective test.

This form of testing may have a much longer process than objective tests, either for students to work on or teachers to assess. However, the final result that impacts students is also much more complex than just a quick answer. Benefits include training students' interpretation, students' ability to organize thoughts, and various other benefits. However, in reality, in the midst of these different circumstances, some of the advantages can turn into weaknesses, including what happens in subjective tests. Online conditions like this make this type of test has a weakness in the implementation process. As happened to the second grade students at SMAN 2 Malang.

This study will focus on identifying forms of weakness faced by teachers and students related to subjective tests of the Javanese language conducted online. This case study will focus on second grade students at SMAN 2 Malang by identifying the subjective tests that have been applied to these students. 
An understanding of the assessment must also be well understood to identify this type of subjective test. A broad understanding will make the identification process easier because assessment is a general concept of the subjective test itself.

In relation to assessment and competence, there is a Teacher Ability Assessment Instrument (IPKG) which is also identified as several basic abilities that a teacher must possess. Teachers are required to be able to formulate learning objectives to be achieved, and choose and organize material well by choosing learning resources that are suitable for students. Teaching techniques must also be adapted to the needs of learning objectives and the conditions of the class and students, which in the end, a teacher is required to be able to conduct an assessment [3]. By paying attention to some of the abilities that teachers must-have, the ability to judge is the end to achieving learning goals. So that the assessment must be well organized and shaped by selecting the form of the test that is used as a means to find the final result.

One type of test used in education throughout Indonesia or even the world is a subjective test. Even not only in the world of education, other fields also often use this subjective test as a form of assessment to determine the cognitive level of the target to be achieved. Mertlers [4] said that the subjective test is one type of test that is believed by many educators that in the process of developing the subjective test can straightforwardly develop skills, especially in writing skills, although there is still a lot of intense practice needed to be able to perfect it [4]. The type of subjective test itself can be divided into two, between short-answers and essay items. This form has its characteristics, advantages and disadvantages. Implementation and effectiveness again depend on which goals the teacher wants to achieve [5].

Behind all the advantages or disadvantages presented by subjective tests on the assessment process or gathering information from students, the pandemic situation as in the end made this assessment a little difficult to implement. This study will focus on identifying the weaknesses of subjective tests that are presented online to second grade students at SMAN 2 Malang. This identification is based on the current state of the pandemic which is still not possible to carry out face-to-face learning directly.

\section{METHODS}

This study uses a qualitative descriptive approach which will identify weaknesses that occur in the use of subjective tests for the assessment of Javanese language subjects. Researchers will collect data by means of observation of the assignment and form of examinations to students. The data will be obtained by observing the optimization of the use of subjective tests on assessments carried out by teachers. Meanwhile the source of data comes from second-grade students at SMAN 2 Malang. The analysis is done by describing the form of weakness, and then a hypothesis will be formulated to find a solution to the weakness of this subjective test.

\section{RESULTS AND DISCUSSION}

The advantages of subjective tests are also in fact, not fully applicable during a pandemic like this. This form of online learning causes what should be an advantage, turning into a subjective test's weakness. Several reasons ultimately make this test weak. The identification will clearly be explained as follows.

\subsection{Economic Gap}

It is undeniable that the current pandemic has impacted the economic situation of the entire world community. Starting from employees and workers who had to lose their jobs due to termination of employment, business actors were also forced to go out of business because many community activities were only carried out at home. This increasingly limited income is not in line with existing solutions in the world of education. The distance learning method requires students to then have a device supported by certain features to support this learning method, coupled with the quota that must be available because some of the features needed must use an internet network connection. The socio-economic status of parents will encourage the provision of access to the necessary learning facilities for children [6].

Supporting tools like that obviously require a lot of money. But that reality contradicts the circumstances that must be experienced in this pandemic. Often this becomes an obstacle in teaching and learning activities, in addition to video conferencing, the form of subjective tests will of course also use much more internet data when compared to objective tests, which require a shorter time. Whether it's true or not, especially for second grade students of SMAN 2 Malang, it often makes the device and internet network unavailable for not or late in doing assignments. Students cannot be blamed for this, because they see the impact caused by the current pandemic has penetrated all elements of people's lives, including in the world of education.

The economic gap may not directly impact the effectiveness of using subjective tests, but one of the characteristics of this test is the duration of the work which tends to be long, especially if the teacher uses the google form feature in the process, so that the use of data will also increase. This reason may be a consideration to further optimize the selection of the type of test that will be given to students, especially in distance learning like this. There are several options for using subjective tests to further minimize the optimal use of internet data. This is because subjective tests do not necessarily have to be eliminated, but rather to be optimized, because of this 
subjective test, students' thinking can be much more developed. Short answers can be a solution for teachers to make subjective tests much more optimal, so that the problem of economic inequality can be more suppressed. Attention like this must really be paid attention to, especially teachers cannot directly monitor what the needs of students are due to the current distance learning process.

\subsection{Reduced Validity}

Subjective tests are actually more valid if used to measure the level of students' ability to organize their thoughts. However, in this online learning situation, the level of validity for these measurements seems to fade, because teachers cannot directly monitor how students interpret the answers given in each form of assignment or exam. Even at SMAN 2 Malang students on the Javanese language exam, it was once known that the use of the same device was used for different students. Obviously this makes the form of the validity of the assessment also reduced. The facts or problems as above may also be possible because of the relationship with problems related to economic inequality experienced by some students, so that the level of validity of the assessment process also decreases.

Seeing such a situation requires the ability of teachers to organize teaching materials and assignments to be much more effective. If it is felt that the level of validity of an assessment is still relatively high, this form may still be maintained in assignments or exams. However, like the use of subjective essay tests, if the level of validity decreases, it can be shifted to the form of short answers, but with the same material weight as the test form essay. To further increase the level of validity, the teacher can combine the form of assignment with the learning process, especially by using an oral form instead of a written one. The teacher can also collect other information that can increase the level of validity of this subjective test.

\subsection{Laziness Rate Increases}

Particularly on the subject of Javanese language, which is only as local content at SMAN 2 Malang. The problem of student laziness existed even before the current pandemic situation. It is the same as what was conveyed by Daud, that factors from within the students themselves are usually internal factors with various forms and types[7]. However, with distance learning, the teacher's control over students is also reduced, so it can be said that this causes the level of student laziness to be higher than learning activities at school. Such disparaging traits make it more challenging to assess cognitively using this type of subjective test. The level of student laziness can be identified from the reduced level of student participation when the assessment process uses subjective tests.
With circumstances like this and coupled with the use of subjective tests, it seems that it is increasingly increasing students' laziness to be able to complete assignments or exams using subjective tests. In addition to requiring interpretation from each student, in Javanese language subjects, students must also be able to use grammar in answering every form of question in good language. So, in such cases, sometimes rewards are one of the factors that can increase students' enthusiasm for learning even in pandemic conditions like today.

\subsection{HOTS (High Order Thinking Skill) target is not right}

It is undeniable that subjective tests are one of the processes that can be taken in gathering information related to higher-order thinking processes [8]. This is because in applying subjective tests, students are required to develop arguments obtained from the answers that will be used to answer each question given. With the subjective test of students, it will also be possible to develop the thinking ability of each individual. However, in the application process of subjective tests, especially in online situations like today, making the target to achieve HOTS is not appropriate. Previous problems such as the level of laziness of students in the process of working on subjective tests resulted in the development of student's abilities to be inappropriate and maximal. Students tend to underestimate what should be done, affecting the development process and students' thinking power. Online subjective tests hinder the process of direct supervision by the teacher to students. Students also do not get enough stimulus to be able to develop their thinking skills. Several classifications can identify the form of weakness.

\subsubsection{Low Troubleshooting}

Troubleshooting is a form of HOTS. This ability can be developed with various stimuli, one of which is by using an intermediary subjective test. Subjective tests allow students to develop their own thinking power and the various problems they face. In contrast to the objective test where the answers are already available, while through the subjective test students are required to seek and find the best answers to the available answers.

However, the implementation of online subjective tests resulted in the problem solving process of students being low. Students expect more to be understood because of circumstances that are not possible. Problem solving is based not only on the results achieved by students but also on the process carried out by students. The teacher will see how students interact with each other, try to formulate solutions to problems, and finally be able to solve them. The online situation hinders the process, and as shown on subjective tests in the assignment of Javanese subjects, problem-solving skills 
appear to be low. Student initiative is much reduced compared to the face-to-face learning process. Students tend to be indifferent to online processes which results in low levels of problem-solving abilities.

\subsubsection{Reluctant to Make Decisions}

The relationship between the decision-making process and the level of student laziness towards online teaching and learning activities is clearly visible. This ability is not possessed by all students, because the dependence on the character of each student is also greatly influenced, so proper guidance and direction are needed to be able to direct this ability. Decision-making is strongly influenced by the ability to think. Before students can make decisions, students' abilities and thinking power must also be able to develop properly. When in the online teaching and learning process, thinking skills that are not optimal finally affect how students make decisions themselves. Students' reluctance to make decisions can be seen from the more passive attitude shown in the subjective test assessment process. Reluctance is not only shown in the passivity of students but in the process of developing answers and arguments, which are low, which shows the low level of students' willingness to make decisions. Sometimes, the teacher is not looking for the results or answers given by the students, but rather on how the students themselves create the thinking power and processes.

\subsubsection{Decreasing Critical Thinking Level}

In line with the decision-making process, critical thinking can also be developed through subjective tests. The reduced level of critical thinking can cause other wider impacts, such as students who violate school rules, both written and unwritten, which can cause chaos in the school environment [9]. The development of arguments from students that can allow students' thinking to be much more honed. As with other thinking skills, it takes a good correlation between teachers and students to be able to develop this ability. Critical thinking means being able to process more deeply normal thinking. Able to provide arguments that are far more precise than arguments in general. The existence of online learning as it is today is in fact still not able to increase the level of students' critical thinking. Subjective tests that should be able to be a stimulus to further hone students' critical thinking levels actually become weak because the process is carried out online. Barriers from factors inside and outside the student learning process make it difficult for students and teachers to then be able to develop assessment designs that can enable students to improve their critical thinking processes.

\subsection{Difficulty Determining Distinguishing Questions}

The diversity of students in one class is one of the challenges for teachers to be able to map students' cognitive development correctly. Subjective tests allow the teacher to be able to determine the distribution of students according to their abilities so that the class situation will be much more even with the optimal action. The online assessment process makes teacher supervision less, so it is difficult for teachers to determine the distinguishing power of questions based on differences in the character and abilities of each student. This of course, will also hamper the assessment process that is collected through subjective tests. The ineffectiveness of subjective tests on students during this pandemic will make progress unable to be monitored in terms of the level of validity and accuracy of the assessment process for student learning outcomes.

With such circumstances, teachers are required to be much more sensitive to the development of their students, especially in the cognitive realm, because critical thinking significantly affects the creativity of a student [10]. The power mapping of the questions can be based on previous assessments with much higher reliability and validity level. Such a process will ultimately help teachers because it takes understanding from inside and outside students to be able to complete the information that must be collected in the assessment process.

Especially in Javanese subjects, language skills are needed, especially writing skills. In the process of administering subjective tests, writing skills are far more prominent than other skills. The habit of writing for Javanese language subjects is highly recommended to be able to familiarize students with writing Javanese language arrangements that are in accordance with the rules, because the reality is that nowadays students often ignore this. Through subjective tests and developing students' thinking processes, they can also practice writing skills.

\section{CONCLUSION}

The influence of the current pandemic has affected various sectors, including the realm of education. Various ways that before the pandemic worked well and were optimal, but when the form of learning is changed to an online form, the optimization level of the use of assessment is reduced. Moreover, the teacher becomes extra effort in the effort of assessing students. Teachers can not only complain about the situation, the demands for novelty and innovation in the form of assessment are also getting higher. The most important thing to remember is that the teacher must be able to adapt to the conditions of the school, class, especially the situation of the students he teaches.

Subjective tests are the same as other forms of tests, tests that have advantages and disadvantages. With the pandemic, the level of effectiveness has also become unstable. In a pandemic case like this, this type of subjective test doesn't work properly. In second grade 
students at SMAN 2 Malang subjective test weaknesses can be identified in three ways, economic inequality, reduced validity, and increased laziness. It takes additional enthusiasm and learning innovation in accordance with the needs of the class to be able to increase the effectiveness of this type of test. The selection of other types of tests can also be used as a solution if the subjective test itself is not optimal for use with students.

\section{REFERENCES}

[1] I. F. Ahmad, "Asesmen Alternatif Dalam Pembelajaran Jarak Jauh Pada Masa Darurat Penyebaran Coronavirus Disease (Covid-19) Di Indonesia," Pedagog. J. Pendidik., vol. 7, no. 1, pp. 195-222, 2020, doi: 10.33650/pjp.v7i1.1136.

[2] A. Riadi, "Problematika Sistem Evaluasi Pembelajaran," Ittihad J. Kopertais Wil. XI Kalimantan, vol. 15, no. 27, pp. 1-12, 2017, [Online]. Available: https://jurnal.uinantasari.ac.id/index.php/ittihad/article/view/1593.

[3] P. Endang, "Konsep Dasar Asesmen Pembelajaran," Konsep Dasar Asesmen Pembelajaran, no. 1, pp. 1-44, 2015.

[4] C. A. Mertler, Action Research: Improving Schools and Empowering Education, 5th ed. California: SAGE Publication, 1967.

[5] P. Rejeki, "Efektifitas Gabungan Tes Subjektif Dan Tes Objektif Dalam Mengevalusi Hasil Belajar Fisika Siswa SMP Negeri 11 Banda Aceh," J. Ilm. Mhs. Pendidik. Fis., vol. 1, no. 3, pp. 74-78, 2016.

[6] W. Rahayu, "Analisis Intensitas Pendidikan oleh Orang Tua dalam Kegiatan Belajar Anak, Status Sosial Ekonomi Orang Tua terhadap Motivasi Belajar dan Prestasi Belajar Siswa," J. Pendidik. dan Pembelajaran, vol. 18, no. 1, pp. 65-71, 2011.

[7] F. Daud, "Pengaruh Kecerdasan Emosional (EQ) Dan Motivasi Belajar Terhadap Hasil Belajar Biologi Siswa SMA 3 Negeri Kota Palopo,' J. Pendidik. dan Pembelajaran Univ. Negeri Malang, vol. 19, no. 2, pp. 243-255, 2012, [Online]. Available:

http://journal.um.ac.id/index.php/pendidikan-danpembelajaran/article/view/3475/626.

[8] M. Yuniar, "Analisis Hots (High Order Thinking Skills) Pada Soal Objektif Tes Dalam Mata Pelajaran Ilmu Pengetahuan Sosial (Ips) Kelas V Sd Negeri 7 Ciamis," Pedadidaktika J. Ilm. Pendidik. Guru Sekol. Dasar, vol. 2, no. 2, pp. 187195, 2015.

[9] G. S. Widodo, Hariyono, and F. Hanurawan, "Persepsi Guru tentang Kenakalan Siswa: Studi
Kasus di Sekolah Dasar 'Raja Agung," J. Pendidik. dan Pembelajaran, vol. 23, no. 2, pp. 142-153, 2016.

[10] A. Milasari, "Kualitas Tes Subjektif Berpikir Kritis Materi Keanekaragaman Hayati," vol. 6, no. 1, pp. 21-30, 2015. 